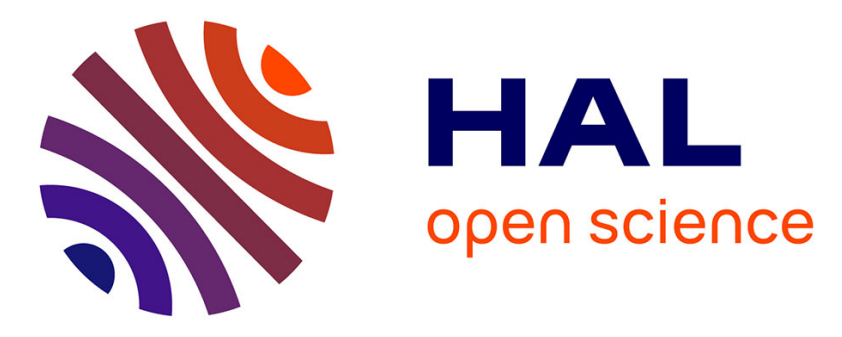

\title{
What are the best indicators to assess malnutrition in idiopathic pulmonary fibrosis patients? A cross-sectional study in a referral center
}

Stéphane Jouneau, Mallorie Kerjouan, Chloé Rousseau, Mathieu Lederlin, Francisco Llamas-Guttierez, Bertrand de Latour, Stéphanie Guillot, Laurent Vernhet, Benoit Desrues, Ronan Thibault

\section{To cite this version:}

Stéphane Jouneau, Mallorie Kerjouan, Chloé Rousseau, Mathieu Lederlin, Francisco LlamasGuttierez, et al.. What are the best indicators to assess malnutrition in idiopathic pulmonary fibrosis patients? A cross-sectional study in a referral center. Nutrition, 2019, 62, pp.115-121. 10.1016/j.nut.2018.12.008 . hal-02088078

\section{HAL Id: hal-02088078}

\section{https://hal-univ-rennes1.archives-ouvertes.fr/hal-02088078}

Submitted on 12 Apr 2019

HAL is a multi-disciplinary open access archive for the deposit and dissemination of scientific research documents, whether they are published or not. The documents may come from teaching and research institutions in France or abroad, or from public or private research centers.
L'archive ouverte pluridisciplinaire $\mathbf{H A L}$, est destinée au dépôt et à la diffusion de documents scientifiques de niveau recherche, publiés ou non, émanant des établissements d'enseignement et de recherche français ou étrangers, des laboratoires publics ou privés. 


\section{Highlights}

- Malnutrition is very frequent in idiopathic pulmonary fibrosis (IPF) patients.

- $\quad$ Low fat-free mass index (FFMI) assessed by bioimpedance analysis (BIA) is reported in $28 \%$ of patients.

- $\quad$ Body mass index (BMI) and mid-arm circumference (MAC) are independently associated with low FFMI.

- A two-step nutritional assessment based on BMI, MAC and BIA should be routinely performed in IPF patients. 
What are the best indicators to assess malnutrition in idiopathic pulmonary fibrosis patients? A cross-sectional study in a referral centre

Stéphane Jouneau, ${ }^{1,2}$ Mallorie Kerjouan, ${ }^{1}$ Chloé Rousseau, ${ }^{3}$ Mathieu Lederlin, ${ }^{4,5}$ Francisco Llamas-Guttierez, ${ }^{6}$ Bertrand De Latour, ${ }^{7}$ Stéphanie Guillot, ${ }^{8}$ Laurent Vernhet, ${ }^{2}$ Benoit Desrues, ${ }^{1,9}$ and Ronan Thibault ${ }^{10,11}$

${ }^{1}$ Department of Respiratory Medicine, Competence Centre for Rare Pulmonary Diseases, CHU Rennes, Univ Rennes, Rennes, France

${ }^{2}$ IRSET UMR1085, Univ Rennes, Rennes, France.

${ }^{3}$ Centre d'Investigation clinique, INSERM 1414, CHU Rennes, Univ Rennes, Rennes, France ${ }^{4}$ Department of Radiology, CHU Rennes, Univ Rennes, Rennes, France

${ }^{5}$ LTSI, INSERM U1099, Univ Rennes, Rennes, France

${ }^{6}$ Department of histopathology, CHU Rennes, Univ Rennes, Rennes, France

${ }^{7}$ Department of Thoracic Surgery, CHU Rennes, Univ Rennes, Rennes, France

${ }^{8}$ Department of Pulmonary function testing, CHU Rennes, Univ Rennes, Rennes, France ${ }^{9}$ Chemistry, Oncogenesis and Stress Signalling, INSERM U1242, Centre Eugène Marquis, 35042 Rennes, France

${ }^{10}$ Unité de Nutrition, CHU Rennes, Univ Rennes, Rennes, France

${ }^{11}$ INRA, INSERM, Univ Rennes, Nutrition Metabolisms and Cancer, NuMeCan, Rennes, France

Funding source: none.

Corresponding author: 


\section{Prof. Ronan THIBAULT}

Unité de Nutrition

\section{CHU Rennes}

2, rue Henri Le Guilloux

35000 Rennes

France

Tél. +33299289646

Fax +33299282434

E-mail ronan.thibault@chu-rennes.fr

$\underline{\text { Running title: }}$ malnutrition in idiopathic pulmonary fibrosis 


\section{ABSTRACT}

Background \& aims: Little is known about the indicators to assess malnutrition in patients with idiopathic pulmonary fibrosis (IPF). This study aimed to determine: i) the prevalence of malnutrition in IPF patients, ii) the nutritional indicators predictive of low fat-free mass (FFM) as measured by bioimpedance analysis; iii) the IPF patients' characteristics associated with low FFM. Methods: The IPF patients were consecutively recruited in a referral centre for Rare Pulmonary Diseases. Malnutrition was defined as a fat-free mass index $($ FFMI $)=$ FFM $(\mathrm{kg}) /\left(\right.$ height $\left.(\mathrm{m})^{2}\right)<17$ (men) or $<15$ (women). Nutritional assessment included body mass index (BMI), mid-arm circumference (MAC), triceps skinfold thickness, analogue food intake scale, and serum albumin and transthyretin. Primary endpoint: FFMI. Statistics: area under the receiver operating characteristic curve (AUC) assessed low FFMI prediction from nutritional indicators. Multivariable logistic regression: variables associated with low FFMI. Results: Eighty-one patients were consecutivély recruited. Low FFMI prevalence was 28\% (23/81). BMI AUC was 0.91 [95\% CI, 0.84-0.97] and MAC AUC was 0.85 [0.76-0.94]. Multivariable analysis associated BMI (Odds ratio (OR) 0.26 [95\% confidence interval (CI) $0.12-0.54], \mathrm{P}=0.0003)$, male gender (OR 0.02 [0.00 - 0.33], $\mathrm{P}=0.005)$, and smoking (OR $0.10[0.01-0.75], \mathrm{P}=0.024)$ with a lower risk of malnutrition. Conclusion: Malnutrition occurred in nearly one third of IPF patients. Malnutrition screening should become systematic, based on BMI and MAC that are good clinical indicators of low FFMI. We propose a practical approach to screen malnutrition in IPF patients.

Keywords: malnutrition; lean body mass; food intake; bioelectrical impedance analysis; interstitial lung disease. 


\section{INTRODUCTION}

Idiopathic pulmonary fibrosis (IPF) is a chronic, progressive, and irreversible lung disease with a poor prognosis and a median survival after diagnosis of $3-5$ years (1-3). IPF is the first aetiology of chronic idiopathic interstitial pneumonia in adults, and is associated with several comorbidities (4). Malnutrition, defined as low body mass index (BMI) or low fat-free mass (FFM) (5-8), is an independent predictor of mortality in patients with chronic obstructive pulmonary disease (COPD), another chronic, progressive, and irreversible lung disease. FFM is the nutritional indicator the best correlated with COPD patient's survival (7). Although BMI is widely used to assess nutritional status, it is an insensitive detector of impaired FFM in COPD patients $(7,9)$. Bioelectrical impedance analysis (BIA) is the simplest and most accurate method for assessing body composition in clinical practice $(9,11-13)$. Pulmonary rehabilitation improves the FFM of COPD patients (14). The prognosis for IPF patients with a low BMI (15) or low BMI plus respiratory parameters (16), and low FFM (17) is poor. However, to our knowledge, little is known regarding the nutritional assessment of IPF patients. The IPF management guidelines do not cover nutritional status assessment $(2,18)$ or the nutritional criteria for assessing disease stage and prognosis (2). Therefore it is needed to determine the best indicators for assessing IPF patients' nutritional status. In this crosssectional study in consecutive IPF patients, we aim to assess the prevalence of malnutrition; to identify the most reliable clinical and biochemical nutritional indicators (BMI, weight loss, low energy intake, mid-arm circumference, triceps skinfold, serum albumin and transthyretin) for predicting low FFM diagnosed by BIA; and, using multivariate analysis, to identify the demographic, respiratory, and nutritional variables associated with low FFM. Our results should provide practical advice for detecting early stage malnutrition in IPF patients, form the basis for future prospective randomized controlled trials on IPF patient nutrition, and, at best, should contribute to elaborate nutritional recommendations in future IPF guidelines. 


\section{PATIENTS AND METHODS}

\section{Study design}

This single-centre cross-sectional study used prospective data collection. Patients were recruited from several general hospitals and private physicians, and assessed at Rennes University Hospital (CHU Rennes).

\section{Study population}

The patients were recruited between May and December 2016 at a French tertiary referral centre for IPF: the Competence Centre for Rare Pulmonary Diseases ('Centre de Compétences Maladies Pulmonaires Rares'), Department of Respiratory Medicine, Rennes University Hospital (CHU Rennes), Rennes, France. We collected data from all consecutive patients with stable IPF, as defined in multidisciplinary discussions $(2,18)$ who had been without infection or exacerbation in the eight weeks preceding their first appointment. This study was approved by the hospital Ethic Committee $\left(n^{\circ} 17.53\right)$.

\section{Clinical and biological assessment of nutritional status}

The nutritional status of all patients was assessed by a single pulmonologist physician (SJ). This initial medical consultation included assessment of weight, height, mid-arm circumference (MAC; tape measure) and triceps skinfold thickness (TSF; adipometer). Body mass index was calculated as: weight $(\mathrm{kg}) /\left(\right.$ height $(\mathrm{m})^{2}$. Mid-arm muscular circumference (MAMC) $(\mathrm{cm})$ was calculated as: MAC $(\mathrm{cm})-(\pi \mathrm{x}$ TSF $(\mathrm{cm}))$. Food intake was systematically assessed with the ten-point analogue visual scale of the Simplified Evaluation of Food Intake ${ }^{\circledR}(\mathrm{SEFI} \circledast)$, as previously described (19). Patients moved the cursor on the scale to answer the question: 'How much do you presently eat, ranging from 'nothing at all' (far left 
of the scale) to 'as usual' (far right side of the scale)?' Results were expressed as a number between 0 and 10. Nutritional biological parameters of all patients (serum albumin and transthyretin) and CRP were also measured.

\section{Bioelectrical impedance analysis (BIA)}

Body composition, including FFM, fat mass, total body water, extracellular and intracellular water, and 50-kHz phase angle, were measured with a multifrequency bioimpedance generator/analyser (Quadscan 4000, Bodystat Ltd, Isle of Man, UK). Briefly, patients lay supine with the palms of their hands facing inwards and areas of skin on the backs of their left hand, left wrist, left foot, and left ankle were cleaned with $70 \%$ ethanol and four adhesive electrodes (3M Red Dot T; 3M Health Care, Borken, Germany) were placed on them. An 0.8 $\mathrm{mA}$ electrical current at frequencies of 5, 50,100, and $200 \mathrm{kHz}$ produced by the bioimpedance generator/analyser was used to measure whole-body resistance $(\mathrm{R})$ and reactance $(\mathrm{Xc})(11)$. Phase angles were calculated from: phase angle $\left(^{\circ}\right)=\arctan (\mathrm{Xc} / \mathrm{R}) \times$ $(180 / \pi)$. Fat-free mass index (FFMI) was calculated as: fat-free mass $(\mathrm{kg}) /\left(\right.$ height $(\mathrm{m})^{2}$. FFMI was considered to be low if it was below 17 in men or below 15 in women, as in COPD patients $(8,20)$. The body fat mass index (BFMI) was calculated as: fat mass $(\mathrm{kg}) /($ height $(\mathrm{m})^{2}$.

\section{Respiratory and other data collection}

Demographic (gender, age) and clinical data (disease duration, comorbidities, current drug use, tobacco use, performance of surgical lung biopsy), pulmonary function test (PFT) and six-minute walk test (6MWT) parameters, were collected from the hospital electronic medical database. Dyspnoea was assessed using the New York Health Association (NYHA) scale. 
PFT and 6MWT were performed according to international guidelines $(21,22)$. The gender, age and physiology (GAP) index was calculated as proposed by Ley et al. (23).

\section{Statistical analysis}

Descriptive statistics are expressed as means \pm standard deviations (SD) or medians and interquartile ranges for continuous data, according to their distribution, and as the number of patients (with the percentage in parenthesis, followed immediately by the counts for the numerator/denominator) for categorical data. ROC curves were used to analyse the

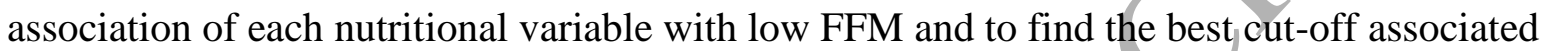
with low FFM by the Youden method. ROC curves were analysed with their AUCs and $95 \%$ confidence intervals (CIs). The discriminative power of the AUC was defined as: $0.90 \leq$ AUC $\leq 1.0$, excellent; $0.80 \leq \mathrm{AUC}<0.90$, good; $0.70 \leq \mathrm{AUC}<0.80$, fair; $0.60 \leq \mathrm{AUC}<0.70$, poor; $0.50 \leq$ AUC $<0.60$, failure (24). We analysed the FFM with $\chi 2$ tests (or Fisher's exact test when appropriate) for categorical data, and Student's $t$-test (or Mann-Whitney-Wilcoxon / Kruskall Wallis test when appropriate) for continuous data. Multivariable logistic regression analysis adjusted for factors with $\mathrm{P}$ yalues of $<0.2$ in univariate analysis was performed with backward stepwise elimination of all variables that did not contribute ( $\mathrm{P}$ value $\geq 0.05$ ). The adjusted Odds ratio of continuous variables was expressed for 1-point increases. Sensitivity, specificity, positive predictive value and negative predictive value, and their $95 \%$ CIs were calculated according to the Youden method. Statistics were computed with SAS software V9.4 (SAS Institute Inc., Cary, NC, USA), and two-tailed P values of $<0.05$ were considered statistically significant.

\section{RESULTS}

\section{Patients' clinical and demographics characteristics}


The study included 81 patients (72 (88\%) men) with IPF whose clinical characteristics are shown in Table 1. The mean age was $74.4 \pm 8.6$ years. Of these, 41 were taking antifibrotic medication at inclusion: $18(32 \%)$ patients with nintedanib (mean duration - $597 \pm 635$ days; range 54 - 1765 days) and 23 (28\%) with pirfenidone (mean duration - $449 \pm 267$ days; range 20 - 1049 days. The remaining 40 patients (49\%) were either taking no antifibrotic medication because they were newly diagnosed $(n=20(25 \%))$, did not tolerate or refuse antifibrotic medication, or their disease was too severe to be treated (i.e. FVC $<50 \%$ pred and/or TLCO $<$ $30 \%$ pred).

\section{Prevalence of malnutrition in IPF patients}

In the 81 IPF patients the prevalence of malnutrition based on BIA, i.e. low FFM, was 28\% (23/81) (Table 2). This prevalence was lower using other definitions: 4\% (3/81) based on $\mathrm{BMI}<21,5 \%$ (4/81) based on MAC ( $<250 \mathrm{~mm}$ in women and $<260 \mathrm{~mm}$ in $\mathrm{men})$, and $9 \%$ (7/81) based on MMAC (<190 $\mathrm{mm}$ in women and <240 $\mathrm{mm}$ in men).

\section{Relationship between fat-free mass and clinical and biological nutrition assessment} parameters

Low FFMI was significantly associated with lower values for BMI, MAC, TSF, and hence MAMC (Table 2). The sensitivity, specificity, positive predictive value, and negative predictive value, defining the capacity of $\mathrm{BMI}<21$ for predicting low FFMI were respectively: $13 \%, 100 \%, 100 \%$, and 74\%. Lower FFMI was associated with a lower $50 \mathrm{kHz}$ phase angle (25) and a higher percentage of fat mass. Patients with low FFMIs were older, more frequently women, non-smokers, had a lower TLCO, and were less likely to be diagnosed using surgical lung biopsy (Table 1). Symptoms (dyspnoea, cough, digital clubbing) or IPF drug therapy were not associated with a low FFMI. Neither were changes in serum albumin 
and serum transthyretin. The variables significantly associated with a reduced risk of low FFMI in multivariable logistic regression were BMI, male gender, and smoking. The capacity of MAC to predict low FFMI was assessed by replacing BMI with MAC in the multivariable model. Two variables were then significantly associated with less risk of low FFMI: MAC (OR 0.48 [0.32 - 0.70], $\mathrm{P}=0.0002)$, and male gender (OR $0.06[0.01-0.46], \mathrm{P}=0.0062)$. We further tested the predictive values of BMI and MAC for low FFMI. The area under the receiver operating characteristic curve assessing low fat-free mass index (FFMI) prediction by BMI was: 0.91 [95\% CI, 0.84-0.97] (Figure 1), and the area for MAC was 0.85 [0.76-0.94] (Figure 2), indicating their excellent (BMI) and good (MAC) discriminative powers for low FFMI. An IPF patient with a $\mathrm{BMI} \geq 25$ and a MAC $\geq 30 \mathrm{~cm}$ was $100 \%$ likely to have a normal FFMI (Table 4). MAMC (AUC $=0.79,95 \% \mathrm{CI}, 0.69-0.90)$ and phase angle $(\mathrm{AUC}=0.72$, $0.61-0.84)$ were both fair predictors of FFMI loss.

\section{Relationship between food intake, nutritional parameters, and IPF drug use}

As reduced food intake is a well-known indicator of malnutrition, we assessed the factors associated with decreased food intake as indicated by the SEFI®. Patients with an SEFI® analogue score of $<7$ had a lower TLCO $(34.4 \pm 13.6 \%)$ than those with a SEFI ${ }^{\circledR}$ score $\geq 7$ (46.0 $\pm 14.9 \%, P=0.0028)$, suggesting a link between decreased food intake and disease severity. Patients with a SEFI® analogue score <7 had lower values for MAC (28.3 \pm 2.7 vs. $29.9 \pm 2.5 \mathrm{~cm}, \mathrm{P}=0.01)$, MAMC $(26.3 \pm 2.6$ vs. $27.6 \pm 2.3 \mathrm{~cm}, \mathrm{P}=0.025)$, and phase angle (4.6 \pm 1.0 vs. $5.2 \pm 0.9$ degrees, $\mathrm{P}=0.012)$ than those with a $\mathrm{SEFI}{ }^{\circledR}$ score $\geq 7$, suggesting a more impaired nutritional status when energy intake is decreased. However, FFMI $(17.7 \pm 3.3$ vs. $18.2 \pm 2.3)$ and the percentage of patients with low FFMI (8/27 (30\%) vs. $15 / 54(28 \%))$ were not statistically different in patients with SEFI® score $<7$ or $\geq 7$. Patients on pirfenidone $(6.9 \pm$ 
2.4) tended to report a lower SEFI® analogue score than patients on nintedanib $(7.4 \pm 2.7)$ or who were untreated $(8.2 \pm 2.3)(\mathrm{P}=0.0516)$.

\section{DISCUSSION}

In this cross-sectional study, nearly one third (28\%) of the IPF patients were malnourished, as defined by a low FFMI based on BIA. Decreased BMI and MAC, female gender, and neversmoking were strong predictors of low FFM. As a low FFMI has been suggested to affect IPF prognosis (17), a systematic nutritional assessment should be routinely recommended for IPF patients.

To our knowledge, this is the first study to determine, in IPF/patients, if usual nutritional indicators could predict low FFMI measured by BIA. Measuring BMI with a cut-off of $<21$, as recommended for COPD patients $(8,14,20)$, is an insensitive method for diagnosing malnutrition, and largely underestimates the problem. It indicated that only $4 \%$ were malnourished, while a low FFMI derived from BIA diagnoses $28 \%$, indicating that $87 \%$ of patients with low FFMI having BMI $\geq 21$ were false negatives. This poor sensitivity of BMI $<21$ has been reported for COPD patients, for whom BIA is the most sensitive method for diagnosing malnutrition $(9,20)$. However, when choosing the right cut-offs, BMI is excellent, and MAC good, at predicting low FFMI. The most discriminative cut-off for BMI was 25.4 with excellent sensitivity and negative predictive value, but the specificity and positive predictive values were poor because it produced many false positives. MAC $<295 \mathrm{~mm}$ and a combination of BMI and MAC gave similar predictive profiles. We believe that these results will prove useful in daily clinical practice.

Our data indicate that malnutrition is common in IPF patients: nearly one third of them were malnourished. This is important because some studies on IPF patients suggested that a low BMI, alone (15) or combined with respiratory parameters (16), and low FFM derived from 
BIA (17), are associated with a poor prognosis. But none of them assessed the prevalence of malnutrition, even based on BMI $<21$ or low FFMI. Alakhras et al. carried out a retrospective analysis of a US cohort of IPF patients and reported the relationship between BMI and mortality (15). Patients with a BMI $\geq 30$ had a better survival rate than those with BMIs $<25$ and 25-30. A retrospective Japanese study on 65 patients with IPF found that a one-point increase in BMI over 12 months was associated with $10 \%$ fewer deaths (16). A recent study of 44 Japanese IPF patients (17) evaluated the prognosis value of FFMI. The FFMI (hazard ratio (HR): $0.64,95 \% \mathrm{CI}: 0.43-0.94, \mathrm{P}=0.02)$ and percentage predicted FVC (HR: $0.96,95 \%$ CI: $0.93-0.99, \mathrm{P}=0.008$ ) were significant predictors of survival. Nutritional status was not correlated with respiratory parameters such as percentage predicted FVC, percentage predicted TLCO, or 6MWT $(15,17)$. We found that the percentage predicted TLCO was significantly lower in IPF patients with a low FFMI. It is now clearly needed to determine whether the prognostic prediction could be improved by combining nutritional and respiratory parameters. A low serum albumin was independently associated with increased mortality in 1269 patients with idiopathic interstitial pneumonia on the waiting list for lung transplantation in the US (26). The clinical profiles of the patients included in these studies differed from those of our patients. In Kishaba et al. study, most of the patients (74\%) were treated with prednisone alone or prednisone plus ciclosporin (16). In Nishiyama et al. study, the patients had lower BMIs, only one had been diagnosed as IPF with a surgical lung biopsy, a lower TLCO, but young patients and those treated with anti-fibrotics ( pirfenidone or nintedanib), or on long-term oxygen therapy were excluded (17). All those diagnosed with idiopathic interstitial pneumonia before the 2011 guidelines for IPF were published (2) had more severe disease and were eligible to lung transplant (26). Our cross-sectional study did not assess the relationship between FFMI and prognosis. A longitudinal study is needed to assess the impact of FFMI on survival according to disease severity, and therapy (oxygen supplements or anti- 
fibrotic medications), in normal clinical practice. Nevertheless, the link between the loss of FFM and prognosis and illness severity emphasises the value of using BIA for managing patients with chronic diseases like IPF.

As expected, those patients with decreased FFMI were relatively old. The fact that patients diagnosed by surgical lung biopsy were less likely to have a low FFMI could be explained by their early diagnosis as they did not have to wait for there to be honeycombing on the chest CT-scan $(27,28)$, indicating more severe disease at the time of nutritional screening. We have no clear explanation why women and non-smokers are so likely to lose FFMI. The mechanisms underlying malnutrition in IPF patients remain unclear. As reported in COPD patients $(29,30)$, anorexia, insulin resistance, inflammation, and hypogonadism could all be involved. However, we found no link between food intake or C-reactive protein (CRP) concentration and FFMI. Nevertheless, the mean CRP concentration in our IPF patients $(8.2 \pm$ $12.1 \mathrm{mg} / \mathrm{L}$ ) was higher than those of COPD patients (3-4 mg/L), who are known to suffer from systemic inflammation $(31,32)$.

We focussed specifically on antifibrotic therapy, but found no difference in the nutritional status of untreated patients and those treated with pirfenidone or nintedanib. However, patients on pirfenidone reported a slight decrease in food intake; this needs to be confirmed. BIA was chosen as the reference method for assessing FFM because it is easy to use for measuring body composition at the bedside or in outpatients (11-13), and has been well validated as an accurate measure of FFM and prognosis assessment in COPD patients (14). Our experience in this study confirmed the ease-of-use of BIA; all the measurements on all patients were obtained by a single physician (SJ) who had never used BIA before. Finally, this study has some limitations. Weight loss was not taken into account as a nutritional parameter, because many data were missing. They were all based on patients' recall and so could be not considered as precise objective data. A longitudinal study is needed 
to assess the predictive value of weight loss for assessing FFMI loss and disease prognosis.

We used the FFMI cut-off values recommended for COPD patients. Nishiyama et al. used the median of FFMI to split their 44 IPF patients (17). The cut-off was $16.6 \mathrm{~kg} / \mathrm{m}^{2}$ for both genders, which is quite similar to the COPD cut-offs we used: women $<15$ and men $<17$. However, more studies are needed to determine the optimal cut-off for defining malnutrition in IPF patients.

We conclude that malnutrition (i.e. low FFMI measured by BIA) is highly prevalent (nearly one third) in IPF patients. Therefore, malnutrition screening should become systematic, based on BMI and MAC that are good clinical indicators of low FFMI. Based on these indicators sensitivity, specificity, positive predictive value, and negative predictive value (Figures 1 and 2, and Table 4), we propose a two-step assessment for malnutrition in IPF patients: 1) first step: measure $\mathrm{BMI}$ and $\mathrm{MAC}$; if $\mathrm{BMI} \geq 25$ and $\mathrm{MAC} \geq 300 \mathrm{~mm}$, patient is likely not malnourished; if $\mathrm{BMI}<21$ or MAC $<295 \mathrm{~mm}$, the patient is likely malnourished: dietician intervention is needed. 2) For all other situations, go to the second step: FFMI measurement by BIA: malnutrition if FFMI <15 (women) or <17 (men). Future studies should assess whether nutritional intervention targeted to FFM, e.g. pulmonary rehabilitation, could change IPF patient outcome.

\section{Statement of authorship}

All authors should have made substantial contributions: SJ and RT conceived, and designed the study, analysed, interpreted the data, and drafted the article; SJ, MK, ML, SG, and LV collected the data; CR analysed the data; BD conceived and designed the study; all authors approved the final version to be submitted.

\section{Conflict of interest statement}


Stéphane Jouneau has received fees, funding or reimbursement for national and international conferences, boards, expert or opinion groups, research projects over the past 5 years from Actelion, AIRB, Astra Zeneca, BMS, Boehringer, Chiesi, Gilead, GSK, LVL, Mundipharma, Novartis, Pfizer, Roche, Savara-Serendex. Ronan Thibault designed the Simplified Evaluation of Food Intake® (SEFI®) (Knoë, le Kremlin Bicêtre, France) tool, and received royalties.

Acknowledgements: The authors thank the 'Association pour l'aide aux insuffisants respiratoires de Bretagne (AIRB)' for providing the bioelectrical impedance analyser, and Dr Owen Parkes for the English language editing of the manuscript. 


\section{References}

1. Ley B, Collard HR, King TE, Jr. Clinical course and prediction of survival in idiopathic pulmonary fibrosis. Am J Respir Crit Care Med 2011;183(4):431-40.

2. Raghu G, Collard HR, Egan JJ, Martinez FJ, Behr J, Brown KK, et al. An official ATS/ERS/JRS/ALAT statement: idiopathic pulmonary fibrosis: evidence-based guidelines for diagnosis and management. Am J Respir Crit Care Med 2011;183(6):788-824.

3. Strand MJ, Sprunger D, Cosgrove GP, Fernandez-Perez ER, Frankel SK, Huie TJ, et al. Pulmonary function and survival in idiopathic vs secondary usual interstitial pneumonia. Chest 2014;146(3):775-85.

4. Raghu G, Amatto VC, Behr J, Stowasser S. Comorbidities in idiopathic pulmonary fibrosis patients: a systematic literature review. Eur Respir J 2015;46(4):1113-30.

5. Chailleux E, Laaban JP, Veale D. Prognostic value of nutritional depletion in patients with COPD treated by long-term oxygen therapy: data from the ANTADIR observatory. Chest 2003;123(5):1460-6.

6. Landbo C, Prescott E, Lange P, Vestbo J, Almdal TP. Prognostic value of nutritional status in chronic obstructive pulmonary disease. Am J Respir Crit Care Med 1999;160(6):1856-61.

7. Schols AM, Broekhuizen R, Weling-Scheepers CA, Wouters EF. Body composition and mortality in chronic obstructive pulmonary disease. Am J Clin Nutr 2005;82(1):53-9. 8. Vestbo J, Prescott E, Almdal T, Dahl M, Nordestgaard BG, Andersen T, et al. Body mass, fat-free body mass, and prognosis in patients with chronic obstructive pulmonary disease from a random population sample: findings from the Copenhagen City Heart Study. Am J Respir Crit Care Med 2006;173(1):79-83. 
9. Thibault R, Le Gallic E, Picard-Kossovsky M, Darmaun D, Chambellan A.

Assessment of nutritional status and body composition in patients with COPD: comparison of several methods. Rev Mal Respir 2010;27(7):693-702.

10. Celli BR, Decramer M, Wedzicha JA, Wilson KC, Agusti A, Criner GJ, et al. An official American Thoracic Society/European Respiratory Society statement: research questions in COPD. Eur Respir J 2015;45(4):879-905.

11. Kyle UG, Bosaeus I, De Lorenzo AD, Deurenberg P, Elia M, Gomez JM, et al. Bioelectrical impedance analysis--part I: review of principles and methods. Clin Nutr 2004;23(5):1226-43.

12. Kyle UG, Bosaeus I, De Lorenzo AD, Deurenberg P, Elia M, Manuel Gomez J, et al. Bioelectrical impedance analysis-part II: utilization in clinical practice. Clin Nutr 2004;23(6):1430-53.

13. Thibault R, Genton L, Pichard C. Body composition: why, when and for who? Clin Nutr 2012;31(4):435-47.

14. Global Initiative for Chronic Obstructive Lung Disease. Global strategy for the diagnosis, management and prevention of chronic obstructive lung disease. 2017. http://www.goldcopd.com.

15. Alakhras M, Decker PA, Nadrous HF, Collazo-Clavell M, Ryu JH. Body mass index and mortality in patients with idiopathic pulmonary fibrosis. Chest 2007;131(5):1448-53. 16. Kishaba T, Nagano H, Nei Y, Yamashiro S. Body mass index-percent forced vital capacity-respiratory hospitalization: new staging for idiopathic pulmonary fibrosis patients. J Thorac Dis 2016;8(12):3596-604.

17. Nishiyama O, Yamazaki R, Sano H, Iwanaga T, Higashimoto Y, Kume H, et al. Fatfree mass index predicts survival in patients with idiopathic pulmonary fibrosis. Respirology 2017;22(3):480-5. 
18. Cottin V, Crestani B, Valeyre D, Wallaert B, Cadranel J, Dalphin JC, et al. Diagnosis and management of idiopathic pulmonary fibrosis: French practical guidelines. Eur Respir Rev 2014;23(132):193-214.

19. Thibault R, Goujon N, Le Gallic E, Clairand R, Sebille V, Vibert J, et al. Use of 10point analogue scales to estimate dietary intake: a prospective study in patients nutritionally at-risk. Clin Nutr 2009;28(2):134-40.

20. Schols AM, Soeters PB, Dingemans AM, Mostert R, Frantzen PJ, Wouters EF. Prevalence and characteristics of nutritional depletion in patients with stable COPD eligible for pulmonary rehabilitation. Am Rev Respir Dis 1993;147(5):1151-6.

21. Miller MR, Hankinson J, Brusasco V, Burgos F, Casaburi R, Coates A, et al. Standardisation of spirometry. Eur Respir J 2005;26(2):319-38.

22. A. T. S. Committee. ATS statement: guidelines for the six-minute walk test. Am J Respir Crit Care Med 2002;166(1):111-7.

23. Ley B, Ryerson CJ, Vittinghoff E, Ryu JH, Tomassetti S, Lee JS, et al. A multidimensional index and staging system for idiopathic pulmonary fibrosis. Ann Intern Med 2012;156(10):684-91.

24. Swets JA. Measuring the accuracy of diagnostic systems. Science $1988 ; 240(4857): 1285-93$.

25. Thibault R, Makhlouf AM, Mulliez A, Cristina Gonzalez M, Kekstas G, Kozjek NR, et al. Fat-free mass at admission predicts 28-day mortality in intensive care unit patients: the international prospective observational study Phase Angle Project. Intensive Care Med 2016;42(9):1445-53.

26. Zisman DA, Kawut SM, Lederer DJ, Belperio JA, Lynch JP, 3rd, Schwarz MI, et al. Serum albumin concentration and waiting list mortality in idiopathic interstitial pneumonia. Chest 2009;135(4):929-35. 
27. Lee JW, Shehu E, Gjonbrataj J, Bahn YE, Rho BH, Lee MY, et al. Clinical findings and outcomes in patients with possible usual interstitial pneumonia. Respir Med 2015;109(4):510-6.

28. Yamauchi H, Bando M, Baba T, Kataoka K, Yamada Y, Yamamoto H, et al. Clinical Course and Changes in High-Resolution Computed Tomography Findings in Patients with Idiopathic Pulmonary Fibrosis without Honeycombing. PLoS One 2016;11(11):e0166168.

29. Eid AA, Ionescu AA, Nixon LS, Lewis-Jenkins V, Matthews SB, Griffiths TL, et al. Inflammatory response and body composition in chronic obstructive pulmonary disease. Am J Respir Crit Care Med 2001;164(8 Pt 1):1414-8.

30. Evans WJ, Morley JE, Argiles J, Bales C, Baracos V, Guttridge D, et al. Cachexia: a new definition. Clin Nutr 2008;27(6):793-9.

31. Agusti A, Edwards LD, Rennard SI, MacNee W, Tal-Singer R, Miller BE, et al. Persistent systemic inflammation is associated with poor clinical outcomes in COPD: a novel phenotype. PLoS One 2012;7(5):e37483.

32. Groenewegen KH, Postma DS, Hop WC, Wielders PL, Schlosser NJ, Wouters EF, et al. Increased systemic inflammation is a risk factor for COPD exacerbations. Chest 2008;133(2):350-7. 


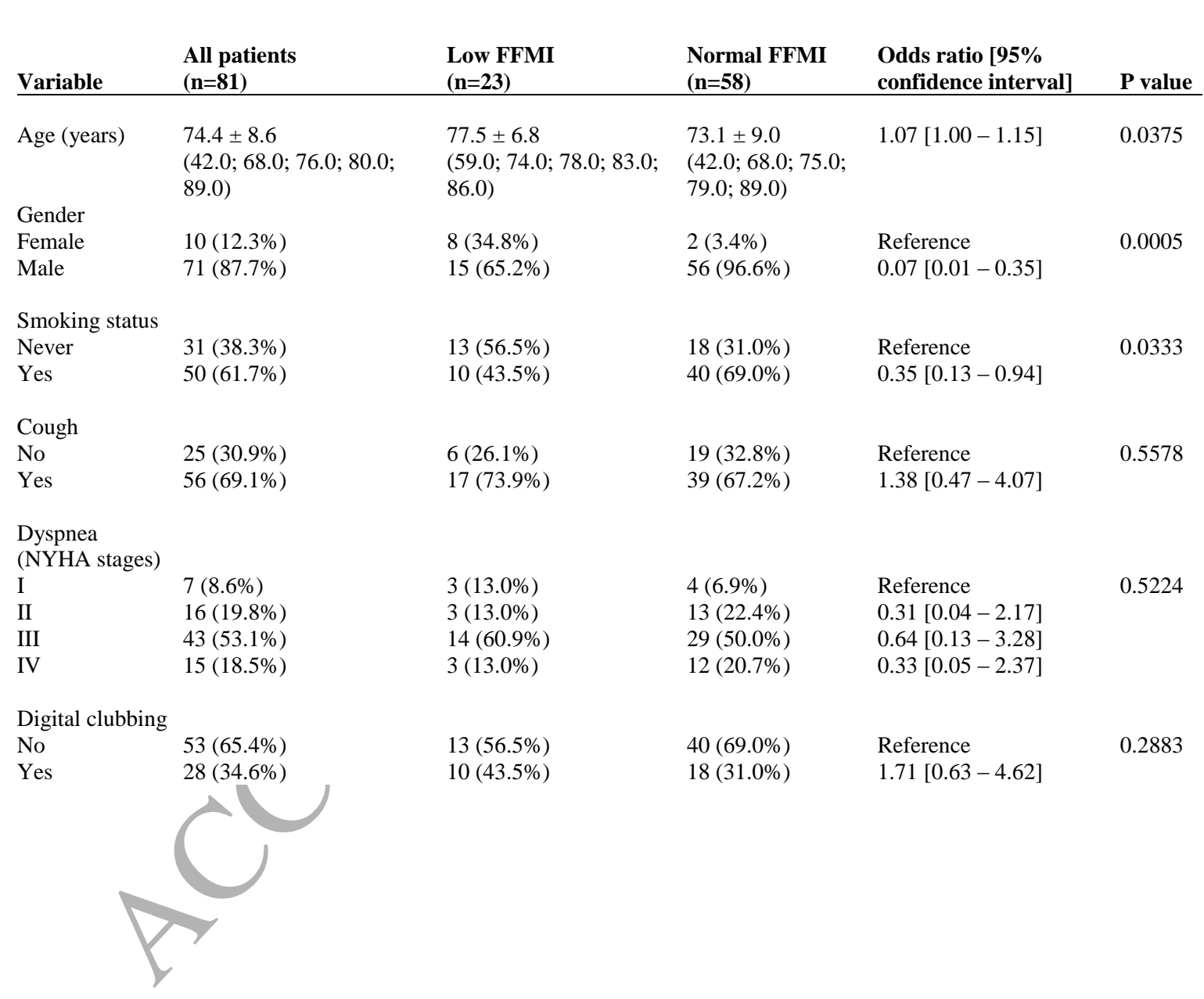




\begin{tabular}{|c|c|c|c|c|c|}
\hline Variable & $\begin{array}{l}\text { All patients } \\
(\mathbf{n}=81)\end{array}$ & $\begin{array}{l}\text { Low FFMI } \\
(\mathbf{n}=23)\end{array}$ & $\begin{array}{l}\text { Normal FFMI } \\
(\mathrm{n}=58)\end{array}$ & $\begin{array}{l}\text { Odds ratio }[95 \% \\
\text { confidence interval] }\end{array}$ & P value \\
\hline$\overline{\mathrm{FVC}}(\%$ pred $)$ & $\begin{array}{l}81.4 \pm 20.2 \\
(25.0 ; 68.5 ; 82.0 ; 96.0 \\
128.0)\end{array}$ & $\begin{array}{l}83.9 \pm 21.1 \\
(44.0 ; 68.0 ; 82.0 ; 100.0 \\
124.0)\end{array}$ & $\begin{array}{l}80.4 \pm 19.9 \\
(25.0 ; 69.0 ; 79.0 \\
95.0 ; 128.0)\end{array}$ & $1.01[0.98-1.03]$ & 0.4886 \\
\hline TLCO (\% pred) & $\begin{array}{l}42.3 \pm 15.4 \\
(14.0 ; 33.0 ; 41.0 ; 54.0 \\
72.0)\end{array}$ & $\begin{array}{l}36.2 \pm 13.8 \\
(14.0 ; 26.0 ; 35.0 ; 39.0 \\
69.0)\end{array}$ & $\begin{array}{l}44.6 \pm 15.5 \\
(18.0 ; 35.0 ; 43.0 \\
56.0 ; 72.0)\end{array}$ & $0.96[0.92-1.00]$ & 0.0404 \\
\hline GAP index & $\begin{array}{l}4.5 \pm 1.5 \\
(2.0 ; 3.0 ; 4.0 ; 5.0 ; 8.0)\end{array}$ & $\begin{array}{l}4.7 \pm 1.5 \\
(2.0 ; 3.0 ; 5.0 ; 6.0 ; 7.0)\end{array}$ & $\begin{array}{l}4.5 \pm 1.5 \\
(2.0 ; 3.0 ; 4.0 ; 5.0 \\
8.0)\end{array}$ & $1.10[0.80-1.53]$ & 0.4753 \\
\hline $\begin{array}{l}\text { GAP class } \\
1 \\
2 \\
3\end{array}$ & $\begin{array}{l}24(29.6 \%) \\
39(48.1 \%) \\
18(22.2 \%)\end{array}$ & $\begin{array}{l}7(30.4 \%) \\
8(34.8 \%) \\
8(34.8 \%)\end{array}$ & $\begin{array}{l}17(29.3 \%) \\
31(53.4 \%) \\
10(17.2 \%)\end{array}$ & $\begin{array}{l}\text { Reference } \\
0.63[0.19-2.03] \\
1.94[0.54-6.99]\end{array}$ & 0.1756 \\
\hline $\begin{array}{l}\text { Time since } \\
\text { diagnosis (days) }\end{array}$ & $\begin{array}{l}626.4 \pm 796.1 \\
(2.0 ; 119.0 ; 376.0 ; 712.0 \\
3967.0)\end{array}$ & $\begin{array}{l}765.3 \pm 1022.9 \\
(23.0 ; 191.0 ; 499.0 ; \\
778.0 ; 3967.0)\end{array}$ & $\begin{array}{l}571.3 \pm 689.0 \\
(2.0 ; 74.0 ; 354.0 ; \\
703.0 ; 2945.0)\end{array}$ & $1.00[1.00-1.00]$ & 0.2646 \\
\hline $\begin{array}{l}\text { Surgical lung } \\
\text { biopsy: No } \\
\text { Yes }\end{array}$ & $\begin{array}{l}61(75.3 \%) \\
20(24.7 \%)\end{array}$ & $\begin{array}{l}21(91.3 \%) \\
2(87 \%)\end{array}$ & $\begin{array}{l}40(69.0 \%) \\
18(31.0 \%)\end{array}$ & $\begin{array}{l}\text { Reference } \\
021[0.04-100]\end{array}$ & 0.0355 \\
\hline $\begin{array}{l}\text { Cancer } \\
\text { No } \\
\text { Yes }\end{array}$ & $\begin{array}{l}73(90.1 \%) \\
8(9.9 \%)\end{array}$ & $\begin{array}{l}21(91.3 \%) \\
2(8.7 \%)\end{array}$ & $\begin{array}{l}52(89.7 \%) \\
6(10.3 \%)\end{array}$ & $\begin{array}{l}\text { Reference } \\
0.83[0.15-4.42]\end{array}$ & 1.0 \\
\hline
\end{tabular}




\begin{tabular}{lllll} 
Variable & $\begin{array}{l}\text { All patients } \\
(\mathbf{n = 8 1})\end{array}$ & $\begin{array}{l}\text { Low FFMI } \\
(\mathbf{n = 2 3})\end{array}$ & $\begin{array}{l}\text { Normal FFMI } \\
(\mathbf{n = 5 8})\end{array}$ & $\begin{array}{l}\text { Odds ratio [95\% } \\
\text { confidence interval] }\end{array}$ \\
\hline $\begin{array}{l}\text { Cardiovascular } \\
\text { comorbidities* }\end{array}$ & & & \\
No & $28(34.6 \%)$ & $9(39.1 \%)$ & $19(32.8 \%)$ & $0.76[0.28-2.06]$ \\
Yes & $53(65.4 \%)$ & $14(60.9 \%)$ & $39(67.2 \%)$ & 0.5866 \\
IPF drug & & & \\
Nintedanib & $18(22.2 \%)$ & $3(13.0 \%)$ & $15(25.9 \%)$ & $0.47[0.11-1.92]$ \\
Pirfenidone & $23(28.4 \%)$ & $8(34.8 \%)$ & $15(25.9 \%)$ & $1.24[0.42-3.71]$ \\
None & $40(49.4 \%)$ & $12(52.2 \%)$ & $28(48.3 \%)$ & Reference
\end{tabular}

2 Qualitative variables: number (\%). Quantitative variables: mean \pm standard deviation (min; Q1; median ; Q3; max). FFMI, fat-free mass index;

3 FVC, forced vital capacity; GAP index, the gender, age and physiology index; TLCO, carbon monoxide diffusion; \% pred; percentage of

4 predicted values. Missing data: FVC, $\mathrm{n}=1$; TLCO, $\mathrm{n}=12$.

*Cardiovascular comorbidities included high blood pressure, history of stroke, myocardial infarction, atherosclerosis, etc... 
7 Table 2- Nutritional assessment of patients with idiopathic pulmonary fibrosis (IPF) (n=81).

\begin{tabular}{|c|c|c|c|c|c|}
\hline Variable & $\begin{array}{l}\text { All patients } \\
(\mathrm{n}=81)\end{array}$ & $\begin{array}{l}\text { Low FFMI } \\
(\mathrm{n}=23)\end{array}$ & $\begin{array}{l}\text { Normal FFMI } \\
(\mathrm{n}=58)\end{array}$ & $\begin{array}{l}\text { Odds ratio }[95 \% \\
\text { confidence interval] }\end{array}$ & P value \\
\hline Clinical parameters & & & & & \\
\hline Weight $(\mathrm{kg})$ & $\begin{array}{l}73.5 \pm 11.4 \\
(41.6 ; 64.0 ; 73.0 \\
; 82.0 ; 95.0)\end{array}$ & $\begin{array}{l}60.7 \pm 6.5 \\
(41.6 ; 57.4 ; 61.0 \\
; 65.0 ; 72.0)\end{array}$ & $\begin{array}{l}78.6 \pm 8.6 \\
(61.0 ; 73.0 ; 77.0 ; 86.0 \\
95.0)\end{array}$ & $0.69[0.58-0.82]$ & $<0.0001$ \\
\hline Body mass index & $\begin{array}{l}26.3 \pm 3.3 \\
(17.3 ; 23.9 ; 26.0 \\
; 29.0 ; 35.3)\end{array}$ & $\begin{array}{l}23.2 \pm 2.0 \\
(17.3 ; 21.9 ; 23.5 \\
; 24.5 ; 27.2)\end{array}$ & $\begin{array}{l}27.6 \pm 2.9 \\
(22.2 ; 25.7 ; 27.5 ; 29.7 \\
35.3)\end{array}$ & $0.42[0.27-0.64]$ & $<0.0001$ \\
\hline $\begin{array}{l}\text { Body mass index }<21 \\
\text { No } \\
\text { Yes }\end{array}$ & $\begin{array}{l}78(96.3 \%) \\
3(3.7 \%)\end{array}$ & $\begin{array}{l}20(87.0 \%) \\
3(13.0 \%)\end{array}$ & $\begin{array}{l}58(100.0 \%) \\
0(0.0 \%)\end{array}$ & $\begin{array}{l}\text { Reference } \\
19.98[0.63-635.32]\end{array}$ & 0.0208 \\
\hline SEFI ${ }^{\circledR}$ score & $\begin{array}{l}7.7 \pm 2.5 \\
(1.0 ; 5.1 ; 8.6 ; \\
10.0 ; 10.0)\end{array}$ & $\begin{array}{l}7.8 \pm 2.8 \\
(1.0 ; 5.0 ; 9.5 ; \\
10.0 ; 10.0)\end{array}$ & $\begin{array}{l}7.6 \pm 2.4 \\
(2.5 ; 5.1 ; 8.0 ; 10.0 ; \\
10.0)\end{array}$ & $1.03[0.85-1.26]$ & 0.4560 \\
\hline $\begin{array}{l}\text { SEFI® score }<7 \\
\text { No } \\
\text { Yes }\end{array}$ & $\begin{array}{l}54(66.7 \%) \\
27(33.3 \%)\end{array}$ & $\begin{array}{l}15(65.2 \%) \\
8(34.8 \%)\end{array}$ & $\begin{array}{l}39(67.2 \%) \\
19(32.8 \%)\end{array}$ & $\begin{array}{l}\text { Reference } \\
1.09[0.40-3.03]\end{array}$ & 0.8617 \\
\hline $\begin{array}{l}\text { Mid-arm circumference } \\
(\mathrm{cm})\end{array}$ & $\begin{array}{l}29.4 \pm 2.7 \\
(21.0 ; 27.5 ; 29.0 \\
; 31.0 ; 35.0)\end{array}$ & $\begin{array}{l}27.2 \pm 2.0 \\
(21.0 ; 26.0 ; 27.0 \\
; 28.5 ; 31.0)\end{array}$ & $\begin{array}{l}30.3 \pm 2.4 \\
(24.5 ; 29.0 ; 30.0 ; 32.0 \\
35.0)\end{array}$ & $0.50[0.35-0.70]$ & $<0.0001$ \\
\hline TSF (mm) & $71+23$ & $5.9 \pm 2.0$ & $7.6 \pm 2.2$ & $0.66[0.51-0.87]$ & 0.0017 \\
\hline
\end{tabular}




\begin{tabular}{|c|c|c|c|c|c|}
\hline Variable & $\begin{array}{l}\text { All patients } \\
(\mathrm{n}=\mathbf{8 1})\end{array}$ & $\begin{array}{l}\text { Low FFMI } \\
(\mathbf{n}=23)\end{array}$ & $\begin{array}{l}\text { Normal FFMI } \\
(n=58)\end{array}$ & $\begin{array}{l}\text { Odds ratio }[95 \% \\
\text { confidence interval] }\end{array}$ & P value \\
\hline & $\begin{array}{l}(3.0 ; 5.0 ; 7.0 ; \\
8.0 ; 14.0)\end{array}$ & $\begin{array}{l}(3.0 ; 4.0 ; 6.0 ; \\
7.0 ; 10.0)\end{array}$ & $(4.0 ; 6.0 ; 8.0 ; 9.0 ; 14.0)$ & & \\
\hline MAMC (mm) & $\begin{array}{l}271.5 \pm 24.8 \\
(197.4 ; 256.2 ; \\
270.6 ; 292.3 ; \\
328.0)\end{array}$ & $\begin{array}{l}253.1 \pm 21.4 \\
(197.4 ; 238.6 ; \\
249.3 ; 269.3 ; \\
300.6)\end{array}$ & $\begin{array}{l}278.8 \pm 22.2 \\
(226.2 ; 264.9 ; 279.6 ; \\
294.3 ; 328.0)\end{array}$ & $0.95[0.92-0.97]$ & $<0.0001$ \\
\hline
\end{tabular}

\section{Bioimpedance analysis}

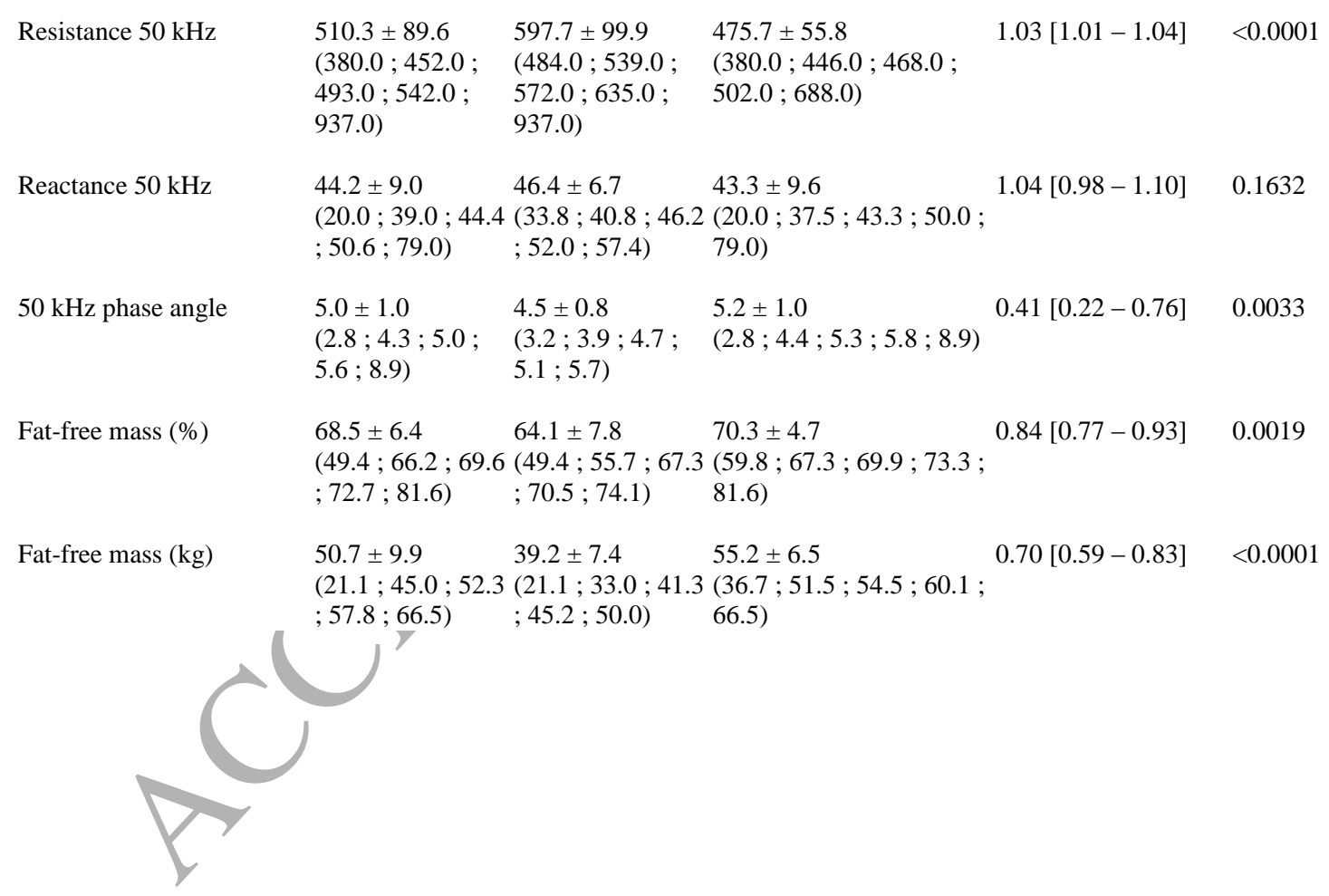




\begin{tabular}{|c|c|c|c|c|c|}
\hline Variable & $\begin{array}{l}\text { All patients } \\
(\mathrm{n}=81)\end{array}$ & $\begin{array}{l}\text { Low FFMI } \\
(\mathbf{n}=\mathbf{2 3})\end{array}$ & $\begin{array}{l}\text { Normal FFMI } \\
(\mathrm{n}=58)\end{array}$ & $\begin{array}{l}\text { Odds ratio }[95 \% \\
\text { confidence interval] }\end{array}$ & P value \\
\hline Fat $(\%)$ & $\begin{array}{l}31.5 \pm 6.4 \\
(18.4 ; 27.3 ; 30.4 \\
; 33.8 ; 50.6)\end{array}$ & $\begin{array}{l}35.9 \pm 7.8 \\
(25.9 ; 29.5 ; 32.7 \\
; 44.3 ; 50.6)\end{array}$ & $\begin{array}{l}29.7 \pm 4.7 \\
(18.4 ; 26.7 ; 30.1 ; 32.7 \\
40.2)\end{array}$ & $1.19[1.08-1.31]$ & 0.0013 \\
\hline Fat mass $(\mathrm{kg})$ & $\begin{array}{l}22.8 \pm 4.6 \\
(14.2 ; 19.4 ; 23.1 \\
; 26.5 ; 34.2)\end{array}$ & $\begin{array}{l}21.5 \pm 4.3 \\
(14.9 ; 18.4 ; 21.2 \\
; 23.8 ; 31.4)\end{array}$ & $\begin{array}{l}23.4 \pm 4.7 \\
(14.2 ; 19.9 ; 23.7 ; 26.6 ; \\
34.2)\end{array}$ & $0.91[0.81-1.02]$ & 0.0909 \\
\hline Fat mass index & $\begin{array}{l}8.3 \pm 2.0 \\
(4.3 ; 7.0 ; 8.1 ; \\
9.6 ; 13.8)\end{array}$ & $\begin{array}{l}8.3 \pm 2.2 \\
(5.2 ; 6.9 ; 7.6 ; \\
9.8 ; 13.8)\end{array}$ & $\begin{array}{l}8.3 \pm 1.9 \\
(4.3 ; 7.0 ; 8.3 ; 9.6 ; 13.7)\end{array}$ & $1.00[0.79-1.28]$ & 0.9708 \\
\hline Total body water (\%) & $\begin{array}{l}55.7 \pm 4.9 \\
(45.2 ; 51.8 ; 55.6 \\
; 58.8 ; 66.7)\end{array}$ & $\begin{array}{l}55.9 \pm 6.0 \\
(45.2 ; 51.6 ; 56.1 \\
; 59.4 ; 66.7)\end{array}$ & $\begin{array}{l}55.6 \pm 4.4 \\
(47.1 ; 51.8 ; 55.3 ; 58.6 ; \\
65.9)\end{array}$ & $1.01[0.92-1.12]$ & 0.8033 \\
\hline Extracellular water (\%) & $\begin{array}{l}24.3 \pm 2.1 \\
(20.3 ; 23.0 ; 24.1 \\
; 25.2 ; 33.2)\end{array}$ & $\begin{array}{l}24.9 \pm 1.8 \\
(22.0 ; 23.6 ; 24.7 \\
; 26.3 ; 28.4)\end{array}$ & $\begin{array}{l}24.0 \pm 2.2 \\
(20.3 ; 22.5 ; 23.7 ; 25.0 ; \\
33.2)\end{array}$ & $1.24[0.97-1.57]$ & 0.0706 \\
\hline Intracellular water (\%) & $\begin{array}{l}30.7 \pm 3.0 \\
(18.6 ; 29.5 ; 31.3 \\
; 32.7 ; 36.1)\end{array}$ & $\begin{array}{l}30.2 \pm 4.1 \\
(23.9 ; 25.9 ; 31.4 \\
; 33.5 ; 35.9)\end{array}$ & $\begin{array}{l}30.9 \pm 2.5 \\
(18.6 ; 29.7 ; 31.2 ; 32.7 ; \\
36.1)\end{array}$ & $0.93[0.79-1.08]$ & 0.4389 \\
\hline Body cell mass $(\mathrm{kg})$ & $\begin{array}{l}32.3 \pm 5.5 \\
(14.8 ; 29.9 ; 33.6 \\
; 36.1 ; 41.8)\end{array}$ & $\begin{array}{l}26.3 \pm 4.8 \\
(14.8 ; 21.2 ; 28.7 \\
; 30.1 ; 32.2)\end{array}$ & $\begin{array}{l}34.7 \pm 3.7 \\
(19.9 ; 33.1 ; 34.9 ; 37.1 ; \\
41.8)\end{array}$ & $0.63[0.51-0.78]$ & $<0.0001$ \\
\hline
\end{tabular}

\section{Biological parameters}




\begin{tabular}{|c|c|c|c|c|c|}
\hline Variable & $\begin{array}{l}\text { All patients } \\
(n=81)\end{array}$ & $\begin{array}{l}\text { Low FFMI } \\
(\mathbf{n}=23)\end{array}$ & $\begin{array}{l}\text { Normal FFMI } \\
(\mathrm{n}=58)\end{array}$ & $\begin{array}{l}\text { Odds ratio }[95 \% \\
\text { confidence interval] }\end{array}$ & $P$ value \\
\hline Serum albumin & $\begin{array}{l}41.9 \pm 3.0 \\
(35.8 ; 39.9 ; 42.3 \\
; 43.9 ; 47.6)\end{array}$ & $\begin{array}{l}41.8 \pm 3.1 \\
(35.8 ; 40.2 ; 42.4 \\
; 44.3 ; 46.5)\end{array}$ & $\begin{array}{l}42.0 \pm 3.0 \\
(35.9 ; 39.8 ; 42.3 ; 43.8 ; \\
47.6)\end{array}$ & $0.98[0.84-1.15]$ & 0.8099 \\
\hline Serum transthyretin & $\begin{array}{l}0.3 \pm 0.1 \\
(0.1 ; 0.2 ; 0.2 ; \\
0.3 ; 0.4)\end{array}$ & $\begin{array}{l}0.3 \pm 0.1 \\
(0.1 ; 0.2 ; 0.2 ; \\
0.3 ; 0.4)\end{array}$ & $\begin{array}{l}0.3 \pm 0.1 \\
(0.1 ; 0.2 ; 0.3 ; 0.3 ; 0.4)\end{array}$ & $1.02[0.40-2.61]$ & 0.9749 \\
\hline $\mathrm{C}$ reactive protein & $\begin{array}{l}8.2 \pm 12.1 \\
(1.0 ; 1.7 ; 3.6 ; \\
8.7 ; 61.6)\end{array}$ & $\begin{array}{l}7.1 \pm 10.1 \\
(1.0 ; 1.5 ; 2.5 ; \\
8.8 ; 38.7)\end{array}$ & $\begin{array}{l}8.6 \pm 12.8 \\
(1.0 ; 1.8 ; 4.4 ; 8.7 ; 61.6)\end{array}$ & $0.99[0.95-1.03]$ & 0.3563 \\
\hline
\end{tabular}

8 Qualitative variables: number (\%). Quantitative variables: mean \pm standard déviation (min; Q1; median ; Q3; max). FFMI, fat-free mass index ;

9 MAMC, mid-arm muscular circumference; SEFI ${ }^{\circledR}$, Simplified Evaluation of Food Intake $®$; TSF, triceps skinfold thickness. Missing data: serum 10 transthyretin, $\mathrm{n}=3$. 
Table 3- Logistic regression multivariable analysis of factors associated with

malnutrition, defined by low fat-free mass index $(\mathbf{n}=\mathbf{8 1})$. The Odds ratio for continuous variables (body mass index) is given for 1-point increases.

\begin{tabular}{lll}
\hline Variables & $\begin{array}{l}\text { Odds Ratio [95\% } \\
\text { confidence interval] }\end{array}$ & P value \\
\hline Body mass index & $0.26[0.12-0.54]$ & 0.0003 \\
Male gender & $0.02[0.00-0.33]$ & 0.0055 \\
Tobacco use & $0.10[0.01-0.75]$ & 0.0243 \\
\hline
\end{tabular}

Fat-free mass index was calculated as: fat-free mass $(\mathrm{kg}) /\left(\right.$ height $(\mathrm{m})^{2}$; below 17 wăs considered to be low or impaired for men and below 15 for women, as for COPD patients (8, 20). 
Table 4- Value of body mass index (BMI) and mid-arm circumference (MAC) for predicting low fat-free mass index (FFMI) in idiopathic pulmonary fibrosis (IPF) patients $(\mathbf{n}=\mathbf{8 1})$.

\begin{tabular}{l|ll|l} 
Variable & Low FFMI & Normal FFMI & Patients (n) \\
\hline $\mathrm{BMI}<25$ and/or MAC $<30$ & 23 & 25 & 48 \\
$\mathrm{BMI} \geq 25$ and MAC $\geq 30$ & 0 & 33 & 33 \\
\hline Patients (n) & 23 & 58 & 81
\end{tabular}

Fat-free mass index (FFMI) was determined by bioimpedance analysis, calculated as: fat-free mass $(\mathrm{kg}) /\left(\right.$ height $(\mathrm{m})^{2}$, and considered to be low or impaired $(<17$ in men $)$ and $(<15$ in women) as for COPD patients $(8,20)$. Sensitivity was $100 \%$ for a BMI $<25$ and/or CMB $<$ 30, $(23 / 23 ; 95 \%$ confidence interval (CI) $88-100 \%)$, while specificity was $57 \%(33 / 58 ; 95 \%$ CI $43-70 \%)$, positive predictive value was $48 \%(23 / 48 ; 95 \%$ CI 33-63\%) and the negative predictive value was $100 \%(33 / 33 ; 95 \% \mathrm{CI} 91-100 \%)$. The BMI and MAC cutoffs associated with low FFMI were assessed by the Youden method. 


\section{Figure legends}

Figure 1- Area under the receiver operating characteristic curve (AUC) assessing body mass index (BMI) prediction of a low fat-free mass index (FFMI) (n=81). FFMI was determined by bioelectrical impedance analysis, and calculated as: fat-free mass $(\mathrm{kg}) /($ height $(\mathrm{m})^{2}$. FFMI was considered low when it was $<17$ in men or $<15$ in women $(8,20)$. A low BMI was associated with a lower fat-free mass index. AUC $=0.91$ [95\% confidence interyal (CI), 0.84-0.97]. The sensitivity, specificity, positive and negative predictive values for a BMI $<25.4$ were: $96 \%, 22 / 23$, [95\% CI, 78-100], 79\%, 46/58, [67-89], 65\%, 22/34, [47-80], and 98\%, 46/47, [89-100]. The BMI cut-off associated with low FFMI was assessed by the Youden method.

Figure 2- Area under the receiver operating characteristic curve (AUC) assessing midarm circumference (MAC) predictions of a low fat-free mass index (FFMI) (n=81). FFMI was determined by bioelectrical impedance analysis (fat-free mass $(\mathrm{kg}) /\left(\right.$ height $\left.(\mathrm{m})^{2}\right)$. FFMI was considered to be low if it was $<17$ in men or $<15$ in women $(8,20)$. A low MAC was associated with a low fat-free mass index. AUC=0.85 [95\% confidence interval (CI), 0.760.94]. The sensitivity, specificity, positive and negative predictive values of a MAC $<295 \mathrm{~mm}$ were: 91\%, 21/23, [95\% CI, 72-99], 66\%, 38/58, [52-78], 51\%, 21/41, [35-67], and 95\%, 38/40, [83-99]. The MAC cut-off associated with a low FFMI was assessed by the Youden method. 
Figure 1
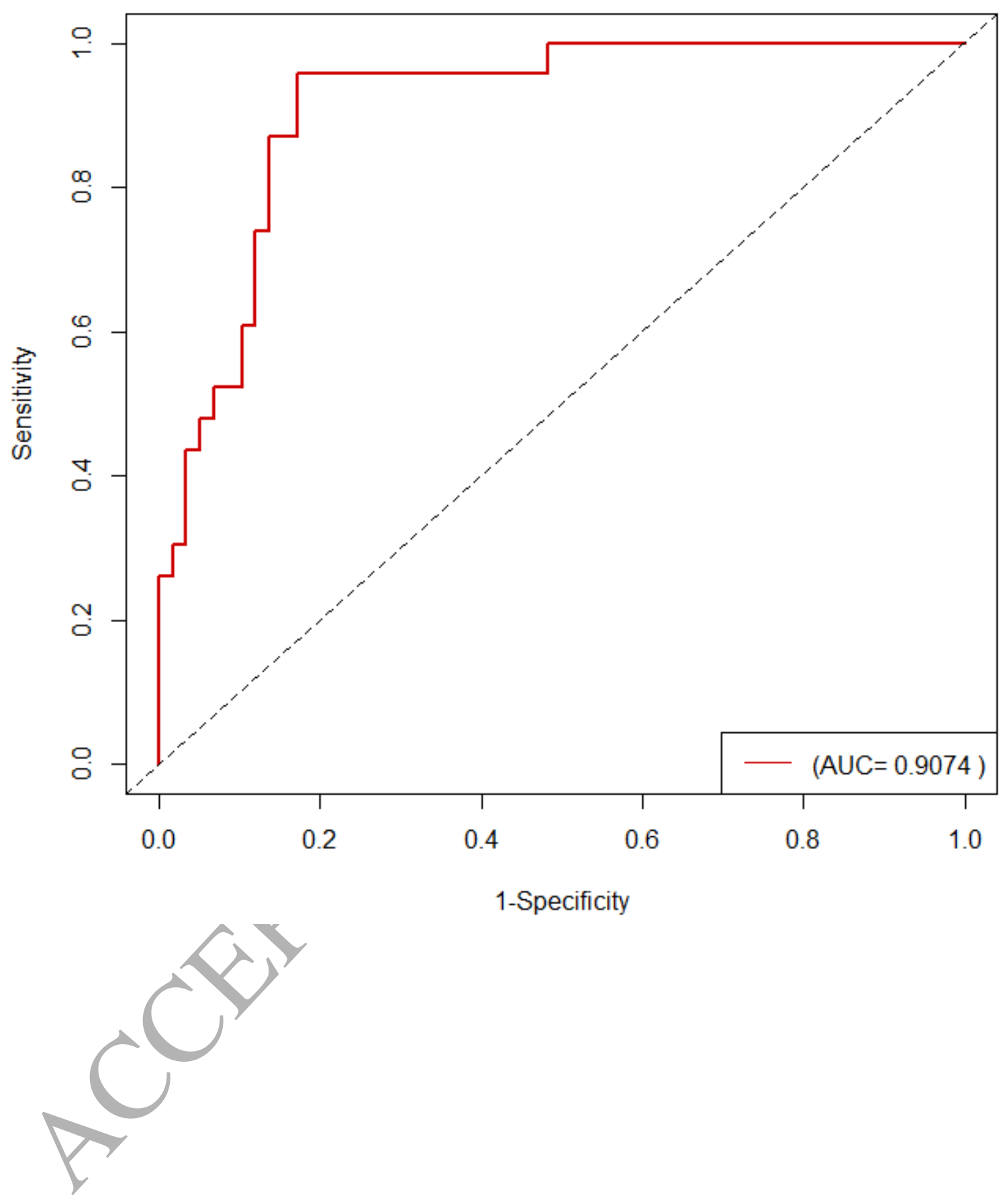
Figure 2
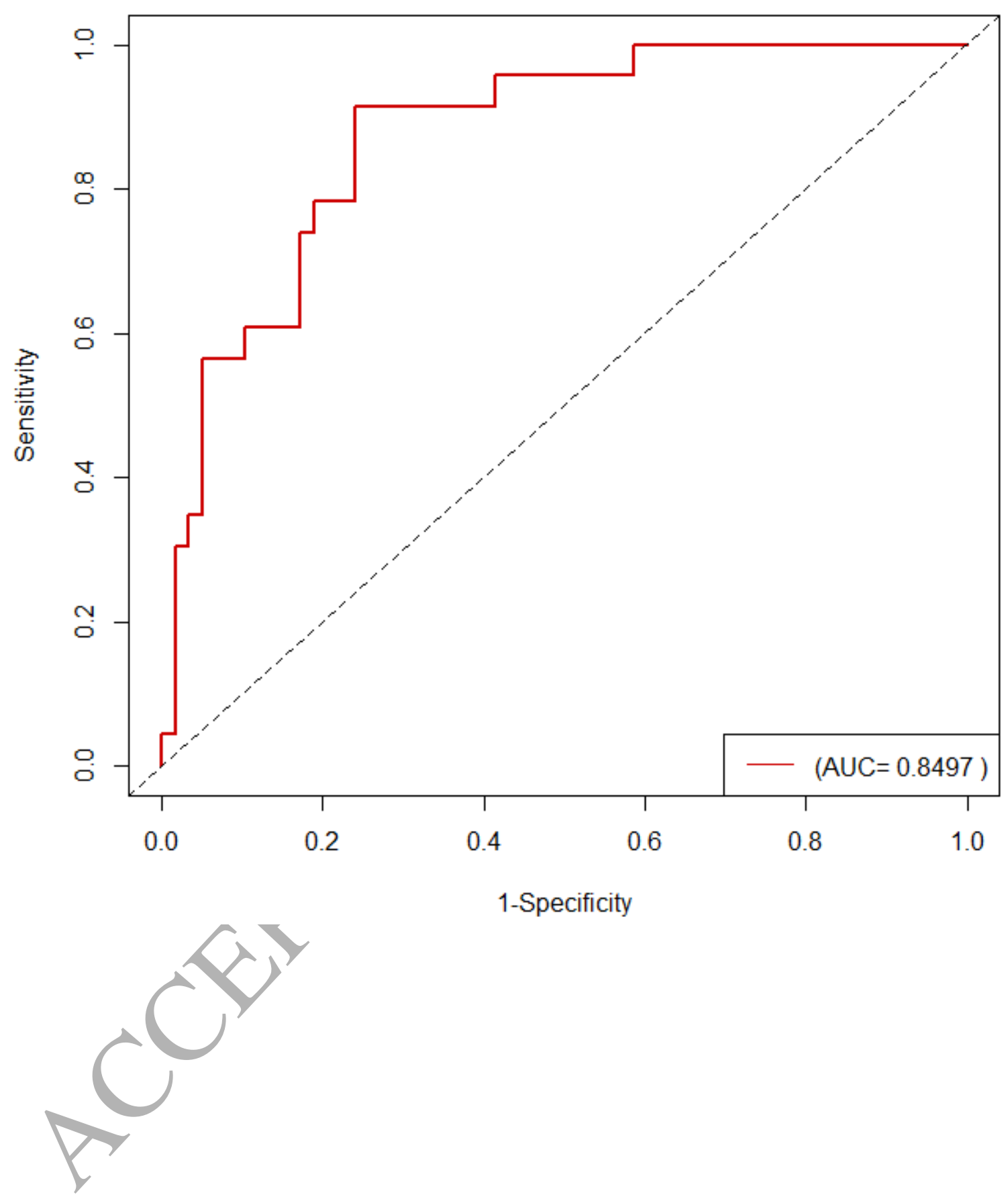